\title{
FAKTOR-FAKTOR YANG MEMPENGARUHI KOMITMEN TERHADAP KARIR DITINJAU DARI ASPEK PERBEDAAN JENDER Studi kasus: Akademisi Perguruan Tinggi Swasta di Yogyakarta
}

\author{
Ninik Sri Rahayu \\ Program Diploma III FE Universitas Islam Indonesia
}

\begin{abstract}
This research purposed to investigate career commitment of academics' staff in Private University of Yogyakarta based on gender perspective. A survey was conducted on 109 women and men academics' staff in Private University of Yogyakarta. The research formulated two hypotheses, Firstly; there are no significant differences in career commitment between women and men academics' staff in Private University of Yogyakarta. Secondly, wage structure, career development and work-home harmonization have significant impact toward career commitment both partially and simultantly.

The Anova results showed that there are no significant differences in career commitment between women and men academics' staff in Private University of Yogyakarta. This research also showed empirical finding that simultantly, all independent variables (wage structure, career development and work-home harmonization) have significant impact on career commitment with $95 \%$ of level confidence. But partially, only career development has significant impact toward career commitment. Career development has the biggest influenced toward career commitment compare to other variables. According that finding, this research recommended that institutions of private university in Yogyakarta need to formulate a career development policy for academics' staff based on gender views.
\end{abstract}

Keyword: career commitment, career development, wage structure and work-home harmonization

\section{PENDAHULUAN}

Berbagai temuan empiris mendokumentasikan bahwa perempuan kerap mendapat perlakuan diskriminatif dalam lingkungan kerja. Hal ini diungkapkan oleh Neumark, D et al (19997) yang menyatakan bahwa pekerja perempuan memperoleh tingkat upah yang lebih rendah dibandingkan pekerja laki-laki pada tingkat kemampuan yang sama. Sementara itu jurnal Wall Sreet seperti diungkapkan oleh Kuntari \& Kusuma (2001) menyebutkan bahwa untuk memperoleh jenjang karir yang lebih tinggi perempuan mendapat hambatan yang lebih besar, fenomena ini sering dimaknai sebagai "the glass ceiling” yang menjadi penyebab turunnya kinerja serta prospek karir perempuan karena terbatasnya kesempatan dalam peningkatan kemampuan dan pengembangan karirnya. Pernyataan tersebut diperkuat oleh Studi yang dilakukan oleh AIM sebagaimana dikutip oleh Harsiwi (2004) yang mengatakan bahwa untuk mencapai posisi eksekutif, perempuan harus bekerja jauh lebih keras daripada laki-laki karena seolah-olah harus memulai dari suatu titik negatif, "For men, starting at "zero", getting to a "plus" is easier. For women, starting from a negative point. Penelitian serupa dilakukan oleh Ul-lslam (1997) yang 
menegaskan diskriminasi terhadap pekerja perempuan berperan dalam mengkonstruksi sikap pasif mereka terhadap komitmen dan kelangsungan karir jika dibandingkan dengan pekerja laki-laki. Truss (1999) berkesimpulan bahwa sikap negatif perempuan di tempat kerja merupakan produk dari kebijakan, praktek dan prosedur manajemen sumber daya manusia yang diskriminatif terhadap perempuan. Sementara itu studi yang dilakukan oleh Md. Mohsin (1997) berkesimpulan bahwa perempuan akan mempunyai sikap dan kesadaran terhadap komitmen karir yang tidak berbeda dengan laki-laki apabila perusahaan memberikan struktur gaji dan kesempatan yang setara antara laki-laki dan perempuan untuk mengembangkan karirnya. Masih dalam domain yang sama Catherine (1997) menghasilkan temuan bahwa bahwa penerapan kebijakan women friendly berdampak positif terhadap QWL (Quality Work of Life).

Diskriminasi dan ketidakadilan yang bersumber pada perbedaan jenis kelamin sesungguhnya terjadi pada hampir semua pilihan pekerjaan atau profesi yang ditekuni perempuan. Selama ini profesi sebagai dosen dalam dunia akademis banyak diminati oleh perempuan karena dianggap mampu menawarkan iklim egaliter antara pria dan perempuan. Namun, anggapan tersebut tidak sepenuhnya benar. Dalam tataran retorika, perempuan memang mendapat kesempatan dan prospek karir yang sama dengan pria, akan tetapi dalam tataran realita masih terjadi marginalisasi dan ketidakadilan terhadap perempuan yang bekerja di dunia akademis. Harsiwi (2004) menjelaskan bahwa meskipun dalam perkembangannya banyak perempuan yang mengenyam pendidikan lebih tinggi dibandingkan dengan pria, akan tetapi hal tersebut tidak berpengaruh nyata terhadap kondisi akademisi perempuan di perguruan tinggi.

\section{RUMUSAN MASALAH}

Dalam kenyataannya, dunia akademis tidak bisa terhindar dari konstruksi sosial yang melahirkan ketidakadilan antara laki-laki dan perempuan (Harsiwi, 2004). Terbentuknya dikotomi peran gender yang berkembang di masyarakat dalam banyak hal telah merugikan perempuan, ketika seorang perempuan bekerja dalam dunia publik dengan sendirinya akan menyandang peran ganda. Beban peran ganda (domestik dan publik) ini berpotensi membentuk komitmen perempuan terhadap karir lebih rendah dibanding laki-laki. Karenanya, kebijakan yang memungkinkan setiap individu dapat mengharmonisasikan kepentingan keluarga dan karir (work-home harmonization) akan mendorong individu tersebut bersikap positif terhadap kelangsungan karirnya. Berbagai temuan ilmiah menyebutkan bahwa rendahnya komitmen perempuan terhadap karir dipicu oleh bentuk-bentuk diskriminasi dalam dunia kerja seperti kebijakan pengembangan karir dan perbedaan struktur gaji. Dengan demikian, penerapan kebijakan-kebijakan tersebut diduga akan membentuk komitmen terhadap karir yang tidak berbeda antara akademisi perempuan dan laki-laki. Relevan dengan isu tersebut penelitian ini merumuskan beberapa pertanyaan yaitu :

1. Apakah terdapat berbedaan komitmen karir antara akademisi laki-laki dan perempuan di Perguruan Tinggi Swasta di Yogyakarta?

2. Bagaimanakah pengaruh struktur gaji, pengembangan karir dan work-home harmonization terhadap komitmen karir akademisi Perguruan Tinggi Swasta di Yogyakarta?

3. Varibel apakah yang paling dominan dalam mempengaruhi komitmen karir akademisi Perguruan Tinggi Swasta di Yogyakarta? 


\section{HIPOTESIS PENELITIAN}

hipotesis yaitu:

Penelitian ini menurunkan dua

1. Tidak ada perbedaan komitmen karir antara akademisi laki-laki dan perempuan di Perguruan Tinggi Swasta di Yogyakarta.

2. Struktur gaji, pengembangan karir dan work home harmonization berpengaruh signifikan terhadap komitmen karir akademisi Perguruan Tinggi Swasta di Yogyakarta.

\section{METODE PENELITIAN \\ Populasi dan Sampel Penelitian}

Populasi dalam penelitian ini adalah staf akademik Perguruan Tinggi Swasta di Yogyakarta. Profil PTS Kopertis V Propinsi DIY dalam www.pts.co.id mencatat jumlah Universitas adalah sebanyak 16 buah dengan total staff akademis sebanyak 2180. Metode pengambilan sampel yang dipilih adalah sample random sederhana (simple random sampling) sehingga setiap elemen populasi memiliki kesempatan yang sama untuk dipilih sebagai sampel.

\section{Penentuan Jumlah sampel}

Penentuan jumlah sampel minimal dalam penelitian ini mengacu pada pendapat Solvin dalam Umar (2001) dengan menggunakan rumus: $\mathrm{n}=\mathrm{N} /\left(1+\mathrm{N} \mathrm{e}^{2}\right)$, dimana: $\mathrm{n}=$ ukuran sample, $\mathrm{N}=$ ukuran populasi, $\mathrm{e}=$ prosentase kelonggaran ketidaktelitian karena kesalahan pengambilan sampel yang dapat ditolelir. Apabila diasumsikan besarnya e adalah $10 \%$ maka secara matematis jumlah sampel minimal yang harus diambil adalah 96 sampel.

\section{Operasionalisasi Variabel Penelitian}

Variabel penelitian dioperasionalkan sebagai berikut:

1. Komitmen karir (Y)

Komitmen karir mengacu pada sikapsikap karir (career attitudes), yaitu bagaimana seorang individu melihat dan mengevaluasi karir mereka. Individu yang memiliki sikap-sikap karir positif akan memiliki komitmen tinggi terhadap karirnya serta berusaha memberikan kontribusi secara optimal terhadap organisasi. Komitmen karir dilihat dari aspek loyalitas terhadap karir, harapan terhadap masa depan karir dan evaluasi karir.

2. Struktur gaji (X1)

Adalah sejumlah komponen gaji yang diterima oleh seorang individu dalam organisasi selama periode tertentu (satu bulan). Variabel struktur gaji ini meliputi gaji pokok, gaji variabel, bonus, kenaikan gaji berkala, tunjangan kesehatan, tunjangan struktural, tunjuangan fungsional, tunjangan perumahan dan tunjangan keluarga.

3. Pengembangan karir (X2)

Adalah kebijakan untuk memberian peluang dan kesempatan bagi seorang individu dalam organisasi untuk meningkatkan kemampuannya secara profesional. Rangkaian pengembangan karir ini meliputi pendidikan dan pelatihan, promosi, pelibatan dalam pengambilan keputusan, pemberian otonomi dan informasi karir.

4. Work-Home Harmonization (X3)

Adalah kebijakan yang diperuntukan bagi seorang individu dalam organisasi agar bisa menyelaraskan atau mengharmonisasikan antara kepentingan karir dan kepentingan keluarga. Variabel ini diukur dari beberapa item seperti lokasi bekerja yang berdekatan dengan rumah, lingkungan kerja yang nyaman, resiko kerja yang rendah, fleksibilitas jam bekerja, pemberian cuti dan tersedianya fasilitas untuk penitipan anak (child care).

5. Gender

Adalah semua atribut sosial mengenai laki-laki dan perempuan, misalnya laki- 
laki digambarkan memiliki sifat maskulin seperti keras, kuat, rasional dan gagah. Sementara perempuan digambarkan memiliki sifat feminin seperti halus, lemah, perasa, sopan, penakut. Perbedaan tersebut dipelajari dari keluarga, tokoh masyarakat, lembaga keagamaan, lembaga pendidikan maupun lingkungan kerja.

\section{Metode Pengumpulan Data}

Dalam proses pengumpulan data digunakan angket yang berisi pertanyaanpertayaan yang ditunjukan kepada responden. Cara pembuatan kuisioner Item kuisioner adalah tipe pilihan ganda, dengan menggunakan skala linkert. Kuisioner penelitian terlebih dulu di uji dengan uji validitas dan reliabilitas. Pengujian diawali uji coba instrumen penelitian dilakukan pada 18 responden yang memiliki karakteristik sama dan tidak termasuk dalam sampel penelitian. Hasil try out menunjukan dua item pertanyaan yang digunakan dalam penelitian tidak valid dimana nilai corrected item-total correlation lebih kecil dari $\mathrm{r}$ tabel sehingga dikeluarkan dari variabel penelitian. Pada penyebaran kuisioner yang sesungguhnya dengan jumlah responden 109 kasus diperoleh besarnya $\mathrm{r}$ tabel 0.1279 ( $\mathrm{df}$ $=108$ dan $=5 \%$ ). Uji reliabilitas dengan pendekatan koefisiean alpha dari Cronbach juga memperlihatkan seluruh instrumen penelitian adalah reliabel.

\section{ANALISIS DAN PEMBAHASAN Analisis Deskriptif}

Responden dalam penelitian adalah akademisi Perguruan Tinggi Swasta (PTS) di wilayah Kopertis V Propinsi Daerah Istimewa Yogyakarta yang berjumlah 109 orang. Berikut ini adalah gambaran singkat responden penelitian jika dilihat dari jabatan struktural, jabatan akademis dan jenjang pendidikan.
Tabel 1 di bawah memperlihatkan data yang cukup menarik dimana hampir setiap kategori jabatan struktural yang tersedia, responden laki-laki menduduki jabatan tersebut, sedangkan responden perempuan kosong pada jabatan pembantu rektor, ketua lembaga penelitian dan sekretaris jurusan. Data tersebut juga menjelaskan bahwa $41 \%$ responden laki-laki menduduki jabatan struktural sedangkan perempuan yang menduduki jabatan struktural sebesar 33.4\%. Apabila dilihat dari jabatan fungsional tertinggi yaitu lektor kepala prosentase laki-laki dan perempuan hampir berimbang yaitu $8.3 \%$ untuk perempuan dan $8.2 \%$ untuk laki-laki. Namun demikian untuk jabatan lektor dan Asisen Ahli prosentase laki-laki memiliki angka lebih besar masing-masing sebesar $36 \%$, sedangkan untuk perempuan memperlihatkan prosentase yang lebih rendah yaitu masing-masing 33.3\% dan $22.9 \%$. Angka-angka tersebut sekaligus menyiratkan bahwa laki-laki yang telah meraih jabatan akademis secara prosentase menunjukan jumlah yang lebih tinggi dibanding perempuan dengan angka perbandingan $80.3 \%$ : $64.5 \%$. Hal ini juga dapat terbaca dari prosentase jumlah lakilaki perempuan yang masih berstatus Non Jabatan Akademis menunjukan perbandingan yang cukup mencolok yaitu 19.7\% untuk laki-laki dan 35.4\% untuk responden perempuan. Sedangkan jika di tilik dari jenjang akademis, prosentase responden laki-laki yang mengenyam pendidikan S3 sebesar 4.9\% sementara perempuan nol \% (tidak ada), untuk yang berpendidikan Master antara laki-laki dan perempuan hampir berimbang, masingmasing 54.2\% untuk perempuan dan $54.1 \%$ untuk laki-laki. Sementara responden yang masih berstatus Sarjana (S1), responden laki-laki menunjukan prosentase yang lebih kecil yakni sebanyak $41 \%$ dan perempuan $45.8 \%$. 
Faktor-faktor yang Mempengaruhi Komitmen terhadap Karir Ditinjau dari Aspek Perbedaan Gender... (Ninik Sri Rahayu)

Tabel 1: Jabatan struktural, Jabatan akademis dan Jenjang pendidikan Responden Berdasarkan Jenis Kelamin.

\begin{tabular}{|c|c|c|c|c|}
\hline \multirow[t]{2}{*}{ Jabatan struktural } & \multicolumn{2}{|c|}{ Frekuensi } & \multicolumn{2}{|c|}{ Prosentase } \\
\hline & Laki-laki & Perempuan & Laki-laki & Perempuan \\
\hline Pembantu Rektor & 1 & - & $1.6 \%$ & - \\
\hline Dekan & 2 & 1 & $3.2 \%$ & $2.1 \%$ \\
\hline Pembantu Dekan & 4 & 2 & $6.6 \%$ & $4.2 \%$ \\
\hline Ketua LP & 2 & - & $3.2 \%$ & - \\
\hline Kaprodi & 3 & 4 & $4.9 \%$ & $8.3 \%$ \\
\hline Sek.Jur & 4 & - & $6.6 \%$ & - \\
\hline Ka. Laboratorium & 4 & 3 & $6.6 \%$ & $6.3 \%$ \\
\hline Koor.Lab & - & 2 & - & $4.2 \%$ \\
\hline Kabiro & 5 & 4 & $8.2 \%$ & $8.3 \%$ \\
\hline Non Jab. Struk & 36 & 32 & $59 \%$ & $66.6 \%$ \\
\hline Total & 61 & 48 & $100 \%$ & $100 \%$ \\
\hline \multicolumn{5}{|l|}{ Jabatan Akademis } \\
\hline Lektor Kepala & 5 & 4 & $8.2 \%$ & $8.3 \%$ \\
\hline Lektor & 22 & 16 & $36 \%$ & $33.3 \%$ \\
\hline Asisten Ahli & 22 & 11 & $36 \%$ & $22.9 \%$ \\
\hline NJA & 12 & 17 & $19.7 \%$ & $35.4 \%$ \\
\hline Total & 61 & 48 & $100 \%$ & $100 \%$ \\
\hline \multicolumn{5}{|l|}{ Jenjang Pendidikan } \\
\hline S3 & 3 & - & $4.9 \%$ & - \\
\hline S2 & 33 & 26 & $54.1 \%$ & $54.2 \%$ \\
\hline S1 & 25 & 22 & $41 \%$ & $45.8 \%$ \\
\hline Total & 61 & 48 & $100 \%$ & $100 \%$ \\
\hline
\end{tabular}

\section{Analisis One Way Anova}

Untuk mengetahui perbedaan komitmen karir antara akademisi laki-laki dan perempuan digunakan uji One Way Anova. Analisa varian (Anova) merupakan metode pengujian yang dapat dipergunakan untuk menguji apakah dua buah sampel mempunyai varian populasi yang sama ataukah tidak. Dalam penelitian ini teknik pengujian Anova menggunakan software SPSS dengan output seperti tampak pada Tabel 2.

Tabel 2 di bawah memperlihatkan bahwa besarnya $\mathrm{F}$ hitung adalah 0.882 dan $\mathrm{F}$ tabel sebesar 3.92. Karena F tabel (3.92) > F hitung (0.882) maka Ho diterima, sehingga kedua rata-rata populasi adalah identik. Artinya secara statistik tidak ada perbedaan komitmen karir antara akademisi laki-laki dan perempuan. Bukti statistik yang menunjukkan bahwa tidak ada perbedaan komitmen karir antara akademisi laki-laki dan perempuan juga bisa diamati dari ringkasan statistik pengujian One way Anova yang terangkum dalam Tabel 3, tabel tersebut memperlihatkan mean (rata-rata) komitmen karir akademisi laki-laki dan perempuan tidak terdapat perbedaan yang tajam. Hal ini ditunjukan oleh nilai mean akademisi lakilaki sebesar 3.8251 sementara untuk akademisi perempuan adalah 3.7152 .

Tabel 2: Uji Anova : Komitmen Karir Akademisi Laki-laki dan Perempuan

\begin{tabular}{cccccc}
\hline & Sum of Squares & $\mathrm{df}$ & Mean Square & $\mathrm{F}$ & Sig. \\
\hline Between Groups & .273 & 1 & .273 & .665 & .417 \\
Within Groups & 43.475 & 106 & .410 & & \\
\hline Total & 43.748 & 107 & & & \\
\hline
\end{tabular}


Tabel 3: Deskripsi Komitmen Karir Akademisi Laki-laki dan Perempuan

\begin{tabular}{|c|c|c|c|c|c|c|c|c|}
\hline & $\mathrm{N}$ & Mean & $\begin{array}{c}\text { Std. } \\
\text { Deviation }\end{array}$ & Std. Error & $\begin{array}{l}95 \% \text { Confidence } \\
\text { Interval for Mean }\end{array}$ & & Min & Max \\
\hline & & & & & Lower Bound & Upper Bound & & \\
\hline Laki-laki & 61 & 3.8251 & .6457 & 8.268E-02 & 3.6597 & 3.9905 & 2.00 & 5.00 \\
\hline Perempuan & 48 & 3.7152 & .6347 & $9.161 \mathrm{E}-02$ & 3.5309 & 3.8995 & 2.33 & 4.67 \\
\hline Total & 109 & 3.7767 & .6403 & $6.133 \mathrm{E}-02$ & 3.6551 & 3.8983 & 2.00 & 5.00 \\
\hline
\end{tabular}

\section{Analisis Regresi Berganda}

Tabel 4: Hasil Regresi

\begin{tabular}{cccccc}
\hline Variabel penjelas & $\begin{array}{c}\text { Koefisien } \\
\text { regresi }\end{array}$ & $\begin{array}{c}\text { Standar } \\
\text { error }\end{array}$ & T statistik & $\begin{array}{c}\text { Koef.Korelasi } \\
\text { Parsial }\end{array}$ & $\begin{array}{c}\text { Koef. Determinasi } \\
\text { Parsial }\end{array}$ \\
\hline Konstata & 0.410 & 0.2808 & 1.846 & & \\
X1 & 0.0126 & 0.056 & -0.224 & $-0,22$ & 0,048 \\
X2 & 0.853 & 0.904 & 19.386 & 0,884 & 0,78 \\
X3 & 0.0239 & 0.038 & 0.622 & 0,061 & 0,004 \\
R- squared & 0.813 & & & & \\
R & 0.902 & & & & \\
F-statistik & 152.022 & & & & \\
\hline
\end{tabular}

Untuk mengetahui pengaruh struktur gaji (X1), pengembangan karir (X2) dan work home harmonization (X3) terhadap komitmen karir (Y) digunakan analisis regresi linier berganda. Dengan menggunakan rumus regresi berganda didapatkan persamaan regresi berganda sebagai berikut: $\mathrm{Y}=0.410-0.0126 \mathrm{X} 1+$ $0.853 \mathrm{X} 2+0.0239 \mathrm{X} 3$

\section{Interpretasi koefisien masing-masing variabel}

Dari persamaan regresi tersebut dapat dilakukan interpretasi koefisien variabel regresi sebagai berikut: a) Nilai konstata sebesar 0.410, menunjukan bahwa komitmen karir akademisi PTS di Yogyakarta adalah positif dengan mengasumsikan bahwa variabel struktur gaji, pengembangan karir dan work-home harmonization nilainya dianggap nol (diabaikan), b) Besarnya nilai koefisien regresi struktur gaji (X1) adalah -0.0126 dan bertanda negatif. Maknanya, secara statistik struktur gaji berpengaruh negatif terhadap komitmen karir akademisi PTS di
Yogyakarta. c) Besarnya nilai koefisien regresi pengembangan karir (X12) adalah 0.853 dan bertanda positif. Artinya, variabel pengembangan karir berpengaruh positif terhadap komitmen karir akademisi PTS di Yogyakarta. d) Besarnya nilai koefisien regresi variabel work home harmonization (X3) adalah 0.0239 dan bertanda positif. Artinya, variabel work home harmonization berpengaruh positif terhadap komitmen karir akademisi PTS di Yogyakarta.

\section{Uji Hipotesis}

Apabila dilihat dari angka koefisien determinasi $\left(\mathrm{R}^{2}\right)$ pada tabel 4 dapat dinyatakan bahwa variabel struktur gaji (X1), pengembangan karir (X2), work-home harmonization (X3) secara bersama-sama mampu menjelaskan variasi variabel komitmen karir sebesar $81.3 \%$ dan sisanya dipengaruhi oleh variabel lain diluar model yang dipergunakan. Sedangkan nilai koefisien korelasi sebesar 90,25\% menunjukkan bahwa hubungan antara komitmen karir dengan tiga variabel independen (struktur gaji, pengambangan karir dan 
work-home harmonization) adalah sangat kuat.

Uji koefisien korelasi secara parsial (uji t) satu arah menggunakan kriteria:

Ho : $\beta_{1}=0$ (variabel independen tidak mempengaruhi variabel dependen)

Ha : $\beta_{1}>0$ (variabel independen mempengaruhi variabel dependen)

Jika t-statistik $>$ t-tabel $(1 / 2=n-k)$, maka Ho diterima dan Jika t-statistik $>$ t-tabel $(1 / 2=n$ k), maka Ho ditolak.

Dengan menggunakan tingkat $\alpha \quad 5 \%$ diperoleh t-tabel sebesar 1.645 sedangkan nilai t-statistik masing-masing variabel independen secara berturut-turut adalah Struktur gaji (X1): -0.224 dengan $\mathrm{r}^{2}=4,8 \%$, Pengembangan karir (X2): 19.386 dengan $\mathrm{r}^{2}$ $=78 \%$, work home harmonization (X3): 0.622 dengan $r^{2}=0,4 \%$. Dari ketiga variabel independen tampak bahwa hanya variabel pengembangan karir (X2) yang memiliki kontribusi positif dan signifikan terhadap komitmen karir. Angka koefisien determinasi parsial menunjukan bahwa secara individual variabel pengembangan karir (X2) mempunyai kontribusi paling dominan terhadap komitmen karir dibanding dengan variabel lainnya.

Sementara itu, pengujian secara serempak Ftest dengan menggunakan kriteria :

Ho : $\beta_{1}=\beta_{2}=\ldots \beta_{\mathrm{n}}=0$ (Variabel-variabel independen secara bersama-sama tidak mempengaruhi variabel dependen)

Ha : $\beta_{1} \neq \beta_{2} \neq \ldots \neq \beta_{\mathrm{n}} \neq 0$ (Variabel-variabel independen secara bersama-sama mempengaruhi variabel dependen)

diperoleh nilai F-hitung sebesar $=152.022$ dan nilai F- tabel $(\mathrm{k}-1, \mathrm{n}-\mathrm{k})=3.07$. Karena F-hitung $>$ F-tabel maka F-hitung berada di daerah penolakan Ho, sehingga secara serentak variabel independen yaitu struktur gaji, pengembangan karir dan work-home harmonization berpengaruh signifikan terhadap komitmen karir akademisi di Yogyakarta.

\section{Pembahasan}

Hasil pengujian Oneway Anova menunjukan bahwa secara statistik tidak terdapat perbedaan komitmen karir antara akademisi laki-laki dan perempuan, sehingga hipotesa pertama dari penelitian ini terbukti. Artinya, komitmen seorang akademisi terhadap karir tidak dipengaruhi oleh faktor gender. Temuan dalam penelitian ini menghasilkan beberapa catatan menarik, Pertama, hasil dari penelitian ini menyanggah riset Ul-Islam (1997) yang menyebutkan bahwa perempuan cenderung bersikap negatif terhadap karir. Sikap tersebut merupakan produk dari kebijakan, praktek, dan prosedur Manajemen Sumber Daya Manusia yang diskriminatif terhadap perempuan. Dalam banyak kasus, pekerja laki-laki lebih disukai dibandingkan dengan pekerja perempuan, hal ini berkait erat dengan berlakunya semacam "anggapan" bahwa adalah tipikal pekerja jangka pendek yang kurang produktif sehubungan hak-hak kodrati yang melekat pada perempuan seperti terpotongnya waktu bekerja untuk melahirkan, cuti haid dan mengurus anak sehingga dianggap tidak menguntungkan perusahaan dalam jangka panjang. Kedua, temuan empiris ini juga berbeda dengan pandangan sementara kalangan yang beranggapan bahwa pekerja perempuan cenderung mempunyai komitmen rendah terhadap kelangsungan karir. Purwani (1995) dalam ulasannya menyebutkan bahwa perempuan "still thingking in term of jobs rather than career", maknanya perempuan masih berpikir dalam kerangka bekerja, bukan karir. Pandangan bahwa perempuan cenderung berkomitmen rendah terhadap karir tidak terbukti dalam penelitian ini. Boleh jadi, adalah benar bahwa dunia akademis merupakan lahan menarik bagi perempuan untuk mengaktualisasikan potensi yang mereka miliki. Selain itu, dunia akademis juga dipandang sebagai sebuah institusi dimana kesetaraan 
gender antara laki-laki dan perempuan adalah suatu hal yang harus diperjuangkan.

Dari analisis regresi berganda, ditemukan bahwa secara serentak variabel struktur gaji, pengembangan karir dan workhome harmonization berpengaruh signifikan terhadap komitmen karir akademisi PTS di Yogyakarta, namun demikian secara parsial hanya variabel pengembangan karir yang mempunyai signifikasi perngaruh terhadap komitmen karir. Dengan demikian hipotesis kedua dalam penelitian ini tidak terbukti. Tidak adanya pengaruh yang signifikan antara struktur gaji terhadap komitmen karir menandakan bahwa kebutuhan mendasar (fisiologis) seperti gaji bagi akademisi telah terpenuhi sehingga komitmen karir lebih dipengaruhi oleh kebutuhan lain seperti misalnya pengembangan karir. Dalam teori Maslow disebutkan bahwa kebutuhan puncak atau paling tinggi dari seorang individu adalah aktualisasi diri, dalam konteks ini, pengembangan karir merupakan perwujudan dari hal tersebut. Sementara itu, variabel work-home harmonization juga tidak berpengaruh nyata terhadap komitmen karir. Hal ini dapat dipahami sebab, dunia akademis memang cenderung menawarkan jam berkerja yang lebih fleksibel terhadap akademisi jika dibandingkan dengan jenis pekerjaan lainnya. Sehingga, tuntutan untuk mengharmonisasikan kepentingan karir dan keluarga tidak lagi menjadi persoalan utama karena jam kerja yang flesibel tersebut.

\section{PENUTUP}

Sebagai penutup, penelitian ini memberikan beberapa rekomendasi, Pertama, variabel pengembangan karir merupakan variabel yang paling dominan pengaruhnya terhadap komitmen karir sehingga kebijakan yang bertalian dengan pengembangan karir hendaknya menjadi perhatian utama dari lembaga perguruan tinggi. Kedua, penelitian berikutnya perlu melakukan wawancara mendalam untuk menggali pengalaman dan harapan-harapan dari akademisi perempuan, karena perempuan dikenal sebagai the silent majority sehingga data-data statistik saja tidak cukup untuk mengungkap fenomena yang dialami oleh perempuan.

\section{DAFTAR PUSTAKA}

Chaterine, et.al. (1997). "Women friendly Human Resources Management Good For QWl? The Case of Hong Kong Based Companies", The International Journal of human Resources management, volume 8:5, hal 644-653.

Harsiwi, Agung. (2004). "Studi Pandangan Akademisi Perempuan Terhadap Prospek Karir dan Kesetaraan Kesempatan di Wilayah Kopertis VI Jawa Tengah” available at www.http://artikel pendidikan.htm

Neumark, David dan Mc Michelle, Lennan. (1999). "Sex Discrimination and Women Labour Market Outcomes", The International Journal of human Resources Management, volume 4.

Purwandari, E. Kristi. (1995). "Aspirasi Perempuan Bekerja dan Aktualisasinya" ("dalam" Ihromi, TO, Kajian Perempuan Dalam Pembangunan)

Rubery, Jill et.al. (1997). "Payment Strukture and Gender Pay Defferential: some Social effect", The International Journal of Human Resources Management, volume 8:3, Hal. 131-149. 
Faktor-faktor yang Mempengaruhi Komitmen terhadap Karir Ditinjau dari Aspek Perbedaan Gender... (Ninik Sri Rahayu)

Sekaran, Uma. (2000). Research Method For Business: Askill-Building Approach, Jhon wiley \& Son, New york, Third Edition.

Setyawati, Trias. (2002). Pengantar Analisis Gender, Makalah dalam seminar Pelatihan Teknik dan Analisis Gender, Yogyakarta, tidak dipublikasikan.

Truss, Catherine. (1996). "Human Resources Gender Terrain?", The International Journal of Human Resources Management, volume 10:2, Hal. 180-199.

Umar, Husein. (2000). Riset Sumber Daya Manusia Dalam Organisasi, PT.Gramedia Pustaka Utama, Jakarta, Edisi revisi dan Perluasan.

Uł Islam, Md. Mohsin. (1997). "Attitude and Consciousness of Japanese Men and Women Toward Career and Commitment and Continuity: The Role of Expected Change in HRM Policies", The International Journal of Human Resources Management, volume 8:3, Hal. 15-169.

www.pts.co.id 